\title{
COVID-19 as an opportunity for smokeless tobacco control and prohibiting spitting in public places
}

\section{Introduction}

Smokeless tobacco (SLT), a highly addictive and ubiquitous form of tobacco is used across 140 countries with 356 million consumers, wherein nearly $82 \%$ reside in the South-East Asia Region (SEAR). ${ }^{1}$ Moreover, out of the 180 parties to the WHO Framework Convention on Tobacco Control (FCTC), 29 countries account for $10 \%$ or more prevalence of SLT use among men, women, or both, which presents a humongous threat to global public health. ${ }^{1}$ Since the outbreak of the novel Corona Virus (COVID-19) pandemic, the clinical outcomes of tobacco users such as their susceptibility to infection and prognosis have been examined. ${ }^{2}$ However, despite the pervasive use of SLT products and the probable risks of SLT use in the context of COVID-19, much of the research has been centered on tobacco smoking. ${ }^{2,3}$

In the SEAR, a few nations have attempted to utilize the pandemic as an opportunity to curb tobacco use. For instance, India prohibited public spitting and made mass appeals to discontinue use of SLT products. ${ }^{4}$ These bans laid the foundation for increased tobacco control in the nation and enabled various states and districts to issue bans on the sale and manufacturing of gutkha and paan masala. These efforts have also been strengthened by national appeals and broadcast by the Prime Minister of India wherein public spitting has been linked to be detrimental to COVID-19 control as well as sanitation programmes like Swachh Bharat Mission.

This ban has been promulgated as an imperative instrument in enabling legal and disciplinary action against violators across several states and Union Territories (UTs) such as Delhi, ${ }^{5}$ Kerala $^{6}$ as well as Gujarat. ${ }^{7}$ However, the compliance to this ban has not been adequately evaluated. Similar appeals have been made in Indonesia ${ }^{8}$ and Sri Lanka ${ }^{9}$ by civil society organizations. However, nations such as Bangladesh ${ }^{10}$ and Bhutan ${ }^{11}$ have forgone this opportunity for the financial contribution of tobacco industry to the economy and to prevent cross-country import to prevent risk of infection. In the SEAR, limited efforts to control SLT use and the accompanying public spitting have been undertaken. To control the COVID-19 pandemic and reduce the arising death toll, it is imperative to develop a united front against SLT use.

\section{Smokeless tobacco use, spitting and Covid-19}

Global tobacco control efforts are fixated on the prevention and cessation of tobacco use in order to curb non-communicable diseases such as cancers, cardiovascular and metabolic disorders. However, while SLT use yields a high risk of non-infective diseases, the rampant use of SLT poses a grim reality for exposure to infectious diseases such as COVID-19. Since the traditional practices of consumption of SLT requires mashing the products in the palms and using fingers to place the product in the oral cavity, often shared among peers, this increases the possibility of transmission from hand to mouth. Further, chewing tobacco or areca nut induces salivation and instigates spitting out the tobacco juice with saliva. ${ }^{3}$ Consequently, post consumption "spitting" is a common sight in public places, which is a neglected yet daunting threat to public health as it makes the entire community susceptible to infectious diseases. ${ }^{12}$ Further, nicotine, which is a major constituent of tobacco products acts as a immunosuppressant. ${ }^{13}$ Thus, SLT and Areca Nut users are more at risk of severe COVID-19 infection due to weakened immunity and accompanying morbidities. ${ }^{3}$

\section{Tobacco control in the midst of Covid-19 pandemic}

Despite the threat to public health, the piece-meal approaches of the countries in the SEAR to curb SLT consumption and public spitting are unfortunate. The COVID-19 pandemic presents a window of opportunity to strengthen tobacco control policies, as public awareness on reducing tobacco use to improve health and well-being is at an unprecedented scale. These approaches can be reinforced through stringent and sustainable tobacco control policies, especially in the nine member states that are parties to the WHO Framework Convention on Tobacco Control (WHO FCTC). Since SLT and areca nut use is primarily endemic to the SEAR, tobacco control policies must be tailored to these regions as fragmented health systems are unable to cope with the demands of cessation support. As temporarily instated by India, a complete ban on the consumption of SLT and areca nut products and public spitting must be mandated across all nations. Further, attempts must be made to understand the linkages of COVID-19 and other infectious disorders with SLT and areca nut use. There is a pressing need to strictly enforce local laws and policies to completely ban manufacture and sale of tobacco products in a phased manner. This will not only limit the easy accessibility to SLT products, but also reduce the vulnerability to several noncommunicable and communicable diseases. Further, provided there is an increased consciousness among the general public due to the ongoing pandemic, this can be utilized to create awareness on the risks of SLT and areca nut use. Adequate cessation support must be provided at the community level which can be further strengthened through the channels of digital health and online support. Multi-sectoral cooperation and political resolve are essential instruments in this battle against the tobacco epidemic which would not only enable alleviation of current tobacco use but also lead to tobacco-free generations.

\section{Funding}

None. 


\section{Declaration of competing interest}

None.

\section{References}

1. Mehrotra R, Yadav A, Sinha DN, et al. Smokeless tobacco control in 180 countries across the globe: call to action for full implementation of WHO FCTC measures. Lancet Oncol. 2019;20(4):e208-e217.

2. van Zyl-Smit RN, Richards G, Leone FT. Tobacco smoking and COVID-19 infection. Lancet Respir Med. 2020;8(7):664-665.

3. Kaur J, Rinkoo AV. Public health perspectives of smokeless tobacco and areca nut use in the COVID-19 era. Nicotine Tob Res. 2020;22(9):1160-1661.

4. Vidyasagaran A, Arora M, Shukla R, Kidwai Z. Policy responses to smokeless tobacco (ST) in India during the COVID19 pandemic | ORF [Internet] [cited $2021 \mathrm{Feb} 18$ ]. Available from: https://www.orfonline.org/expert-speak/policy-responses-to-s mokeless-tobacco-st-in-india-during-the-covid19-pandemic/; 2020.

5. Press Trust of India. Delhi police issues over 1,400 challans for Covid-19 protocol violation | Delhi News - times of India [Internet] [cited 2021 Apr 28]. Available from: https://timesofindia.indiatimes.com/city/delhi/delhi-police-issues-over-1 400-challans-for-covid-19-protocol-violation/articleshow/79248754.cms; 2020.

6. The Hindu. Sectoral magistrates report over 16,000 cases of non-compliance - the Hindu [Internet] [cited 2021 Apr 28]. Available from: https://www.thehindu. $\mathrm{com} /$ news/cities/Kochi/sectoral-magistrates-report-over-16000-cases-of-non-c ompliance/article32923263.ece; 2020.

7. The Indian Express. Gujarat Police collected over Rs 161 crore collected in fine for spitting, mask violations | India News, The Indian Express [Internet] [cited $2021 \mathrm{Apr}$ 28]. Available from: https://indianexpress.com/article/india/gujarat-police-c ollected-over-rs-161-crore-collected-in-fine-for-spitting-mask-violations-7257807/; 2021.

8. International Union Against Tuberculosis and Lung Disease. Indonesian civil society calls for urgent action On tobacco control to reduce impact of COVID-19 [Internet] [cited $2021 \mathrm{Feb} 2$ ]. Available from: https://theunion.org/news/indonesian-civil-soc iety-calls-for-urgent-action-on-tobacco-control-to-reduce-impact-of-covid-19; 2020.
9. Centre for Combating Tobacco. A letter to HE the president, Sri Lanka requesting to ban tobacco sales during the COVID-19 Epidemic [Internet] [cited $2020 \mathrm{Feb} 3$ ]. Available from: http://cct.lk/?p=1784; 2020.

10. Industries Ministry Rejects Tobacco Ban Proposal | Dhaka Tribune.

11. Going Local - COVID-19 Prompts Bhutan to Lift Tobacco Ban | The Economic Times.

12. Kar SK, Pandey P, Singh N. Understanding the psychological underpinning of spitting: relevance in the context of COVID-19. Indian J Psychol Med. 2020 Nov;42(6): 577-578.

13. Chaturvedi P, Mishra A, Datta S, Sinukumar S, Joshi P, Garg A. Harmful effects of nicotine. Indian J Med Paediatr Oncol. 2015 Mar;36(1):24.

Prashant Kumar Singh ${ }^{\mathrm{a}, \mathrm{b}, *}$, Shruti Acharya ${ }^{\mathrm{b}}$, Pankhuri Jain ${ }^{\mathrm{b}}$, Shalini Singh ${ }^{\mathrm{a}, \mathrm{c}}$

${ }^{a}$ WHO FCTC Global Knowledge Hub on Smokeless Tobacco, ICMRNational Institute of Cancer Prevention and Research, Indian Council of Medical Research (ICMR), Noida, 201301, Uttar Pradesh, India ${ }^{\mathrm{b}}$ Division of Preventive Oncology \& Population Health, ICMR- National Institute of Cancer Prevention and Research, Indian Council of Medical Research (ICMR), Noida, 201301, Uttar Pradesh, India

${ }^{\mathrm{c}}$ ICMR - National Institute of Cancer Prevention and Research, Indian Council of Medical Research (ICMR), Noida, 201301, India

* Corresponding author. WHO-FCTC Global Knowledge Hub on Smokeless Tobacco, ICMR- National Institute of Cancer Prevention and Research, Indian Council of Medical Research (ICMR), Noida, 201301, Uttar Pradesh, India. E-mail addresses: prashants.geo@gmail.com (P.K. Singh), acharyashruti97@gmail.com (S. Acharya), pankhuri.pj@gmail.com (P. Jain), shalinisingh.icmr@gmail.com (S. Singh). 